\title{
Synthesis of Borono Fluoro Deoxy D glucose as Boron carrier for Boron neutron capture therapy (BNCT)
}

\author{
Zafer Akan ${ }^{1 *}$, Taner Ozel² ${ }^{2}$ Gokhan Oto ${ }^{3}$, Hulya Ozdemir ${ }^{3}$
}

\begin{abstract}
Objective: The 18F-labeled Deoxy-D-Glucose exhibits high affinity to cancer tissue as a PET (Positron Emission Tomography) imaging agent for metastatic cancers. Complexation of 10B to $18 \mathrm{~F}-\mathrm{DG}$ complex may create a useful BNCT (Boron Neutron Capture Therapy) agent for cancer therapy. In previous studies, complexation and characterization of $10 \mathrm{~B}$ with $\mathrm{DG}$ were evaluated and biodistribution analysis was completed successfully. Radio labeled 10B-DG will be a useful approach for uses for BNCT applications.
\end{abstract}

Methods: The 18F-DG synthesized by ion exchange and complexed with $10 \mathrm{~B}(\mathrm{OH}) 3$ via pH reactions. $18 \mathrm{~F}$ DG-10B complexation was assayed with Agilent 1260 Infinity HPLC-DAD and Agilent 6420 Triple Quad LC/MS. Complexed molecule defragmented and fragmentation products assayed with Agilent 6420 Triple Quad LC/MS for confirmation.

Results: 10B-18F-DG complex was obtained with ion-exchange pH reaction successfully. Complexation of two $10 \mathrm{~B}(\mathrm{OH}) 3$ to $18 \mathrm{~F}-\mathrm{DG}$ was determined with Triple Quad LC/MS. Purification of 10B-18F-DG is currently in progress.

Conclusions: Radio-labelled 10B-DG will supply new insight to research for BNCT studies. Cancer detection and therapy will be applicable in the same schedule with 10B-18F-DG complex.

Key words: Boron Neutron Capture Therapy, Borono 2-Deoxy-D-glucose, Boronophenylalanine, Glucose, 2-Fluoro-2-deoxy-D-glucose

\section{Introduction}

Boron Neutron Capture Therapy (BNCT) is a alternative radiotherapy method used in the treatment of head and neck cancers, especially for Glioblastoma (GBM) and Astrocytoma tumors (1).

Tumour tissue exposes to neutron after boron (10B) accumulation in the tumor cells, neutron exposed 10B's captures the neutrons and nuclear fusion reaction occurs $\left({ }^{10} \mathrm{~B}+{ }^{1} \mathrm{n} \rightarrow{ }^{11} \mathrm{~B} \rightarrow{ }^{7} \mathrm{Li}+{ }^{4} \mathrm{He}+\gamma\right)$. Usually, epithermal energetic neutrons $(0.4 \mathrm{keV}-10$ or $20 \mathrm{keV})$ are used for treatment. Today, clinical trials of BNCT are performed in a few nuclear reactors and BNCT aimed cyclatron include centers $(1,2)$.

Produced cytotoxic 4He's from the fusion reaction, triggers the apoptosis and damages the tumor tissue specifically.

These charged particles can not move too far and release their all energy into the tumor cells, thus damages the DNA and directs to apoptosis the tumor cells. These products, which are the result of irradiation of 10B, have Linear energy transfer (LET) characteristics (LET about $150 \mathrm{keVm}-1$ for $\mathrm{He}$ particle and about $175 \mathrm{keVm}-1$ for $\mathrm{Li}$ ).

The length of these reaction products is between 4.5$10 \mathrm{~nm}$, which is about the diameter of a cell.

The basic reaction of BNCT is as follows:

${ }^{10} \mathrm{~B}+\mathrm{n} \rightarrow{ }^{7} \mathrm{Li}(0.84 \mathrm{MeV})+{ }^{4} \mathrm{He}(1.47 \mathrm{MeV})+\gamma(0.48$ $\mathrm{MeV}$ )

${ }^{10} \mathrm{~B}+\mathrm{n} \rightarrow{ }^{7} \mathrm{Li}(1.01 \mathrm{MeV})+{ }^{4} \mathrm{He}(1.78 \mathrm{MeV})$

Basic problems at BNCT

1- Boron accumulation in to tumour tissue

2 - Neutron source.

For use as a neutron source for clinical trials, beside nuclear reactors, SUMITOMO has produced two 30 MEV energized cyclotrons (HM-30) $(2,3,4,5)$.

In addition to neutron source problem, Boron carriers that are alternative to Boron Phenyl Alanine (BPA) are still being worked on. In previous study ${ }^{10} \mathrm{~B}-\mathrm{DG}$ 
has been synthesized and bio-distribution analysis were completed. In this project, we proposed a reaction for the synthesis of the radioactive labelled boron carrier, Borono-Floro-Deoksi-D-Glucose $\left({ }^{10} \mathrm{~B}\right.$ ${ }^{18}$ F-DG).

${ }^{10} \mathrm{~B}-{ }^{18} \mathrm{~F}-\mathrm{DG}$ complex was obtained with ion-exchange $\mathrm{pH}$ reaction successfully. Complexation of two ${ }^{10} \mathrm{~B}(\mathrm{OH})_{3}$ to ${ }^{18} \mathrm{~F}-\mathrm{DG}$ was determined with Triple Quad $\mathrm{LC} / \mathrm{MS}$ and shown to be an alternative boron carrier to BPA by in-vitro comparison studies $(6,7,8)$.

\section{Material and Methods}

To the compromise, yield of complexation reactions, two different $\mathrm{pH}$ reactions prepared.

Reaction 1 (R1): $\mathrm{pH}: 3$ Reaction: Boric Acid $\left({ }^{10} \mathrm{~B}(\mathrm{HO})_{3}\right.$ : Sigma-Aldrich, Saint Louis, MO, 63103, USA; MW: $61,03 \mathrm{~g} / \mathrm{mol}$ ) solutions has been prepared in $0.08,0.16$ ve $0.32 \mathrm{mM} \mathrm{pH}: 3$ concentrations and ; $0.08 \mathrm{mM}$ 18F-DG $\left(\mathrm{C}_{6} \mathrm{H}_{11}{ }^{18} \mathrm{FO}_{5}, \mathrm{MW}: 181,1495\right.$ $\mathrm{g} / \mathrm{mol}) \mathrm{pH}: 3$. Solutes were mixed and $\mathrm{pH}$ elevated to physiological $\mathrm{pH}: 7,4$ with $\mathrm{NaOH}$.

Reaction 2 (R2): pH:3, pH:11 Reaction: Boric Acid $\left({ }^{10} \mathrm{~B}(\mathrm{HO})_{3}:\right.$ Sigma-Aldrich, Saint Louis, MO, 63103, USA; MW: $61,03 \mathrm{~g} / \mathrm{mol}$ ) solutions has been prepared in $0.08,0.16$ ve $0.32 \mathrm{mM} \mathrm{pH:3} \mathrm{concentrations} \mathrm{and} \mathrm{;}$ $0.08 \mathrm{mM}{ }^{18} \mathrm{~F}-\mathrm{DG}\left(\mathrm{C}_{6} \mathrm{H}_{11}{ }^{18} \mathrm{FO}_{5}, \mathrm{MW}: 181,1495 \mathrm{~g} / \mathrm{mol}\right)$ $\mathrm{pH}: 11$. Solutes were mixed and $\mathrm{pH}$ fixed at physiological $\mathrm{pH}: 7,4$.

$$
\begin{aligned}
& { }^{10} \mathrm{~B}(\mathrm{OH})_{3}+\mathrm{HCl} \rightarrow \mathrm{B}^{+}+\mathrm{H}_{2} \mathrm{O}+\mathrm{Cl}^{-} \quad \mathrm{pH}: 3 \\
& \mathrm{C}_{6} \mathrm{H}_{11}{ }^{18} \mathrm{FO}_{5}+\mathrm{NaOH} \rightarrow \mathrm{C}_{6} \mathrm{H}_{10}{ }^{18} \mathrm{FO}_{5}{ }^{-}+\mathrm{H}_{2} \mathrm{O}+\mathrm{Na}^{+}
\end{aligned}
$$

$\mathrm{pH}: 11$

$\left(\mathrm{B}^{+}+\mathrm{H}_{2} \mathrm{O}+\mathrm{Cl}^{-}\right)+\left(\mathrm{C}_{6} \mathrm{H}_{9}{ }^{18} \mathrm{FO}_{3}{ }^{-}+\mathrm{H}_{2} \mathrm{O}+\mathrm{Na}^{+}\right) \rightarrow$ $\mathbf{2}^{10} \mathbf{B}(\mathbf{O H})_{2}-\mathbf{C}_{6} \mathbf{H}_{10}{ }^{18} \mathbf{F O}_{5}+\mathrm{NaCl}+\mathrm{H}_{2} \mathrm{O}$

$\mathrm{pH}: 7$

The ${ }^{18} \mathrm{~F}$-DG complexed with ${ }^{10} \mathrm{~B}(\mathrm{OH})_{3}$ via low-high $\mathrm{pH}$ reaction. ${ }^{18} \mathrm{~F}-\mathrm{DG}-{ }^{10} \mathrm{~B}$ complexation was assayed with Agilent 1260 Infinity HPLC-DAD and Agilent 6420 Triple Quad LC/MS. Complexed molecule defragmented and fragmentation products assayed with Agilent 6420 Triple Quad LC/MS for confirmation.

For ${ }^{10} \mathrm{~B}$ uptake compromise analysis: 0, 20, 40, 80 $\mu \mathrm{g} / \mathrm{ml}$ 10B-18FDG and 10BPA were prepared; Mat LyLu: ATCC JHU-92 cell line $\left(5 \times 10^{6}\right.$ cell) maintained in $\mathrm{CO} 2$ incubator at $370 \mathrm{C}, 0.5 \mathrm{CO}_{2}$, RPMI1640, 10\% FCS, $0.5 \%$ penicillin/streptomycin (Sigma Aldrich).

For ${ }^{10} \mathrm{~B}$ uptake compromise analysis at different concentrations ${ }^{10} \mathrm{~B}-{ }^{18} \mathrm{FDG}(0,20,40,80 \mu \mathrm{g} / \mathrm{ml})$ and 10BPA were add to Mat LyLu cell suspension and incubated for 4 hours. Then cells were washed with phosphate buffer saline (PBS; Sigma-Aldrich, SigmaP4417) solutions for three times and lysed with ultrasonography.

Cell debris centrifuged and clean intracellular solution used for 10B analysis in Agilent 7700 ICP-MS analysis.

\section{Results}

Concentration depending elevation of ${ }^{18} \mathrm{~F}-\mathrm{DG}$ shift has been shown in figure 1 by HPLC analysis $\left({ }^{18} \mathrm{~F}-\mathrm{DG}\right.$ $0.08,0.16$ ve $0.32 \mathrm{mM}$ ). (Agilent 1260 Infinity HPLCDAD) (Figure 1).

For complexation reaction $0.08 \mathrm{mM}$ 18F-DG complexed with $\mathrm{B}(\mathrm{OH})_{3}$ in three different concentrations $(0.08,0.16$ ve $0.32 \mathrm{mM})$ with two different $\mathrm{pH}$ approaches $(\mathrm{R} 1, \mathrm{R} 2)$ in figure 2 .

Due to peak shifts, the best yield of complexation reaction observed in ${ }^{10} \mathrm{~B}(\mathrm{OH})_{3}(0.32 \mathrm{mM}) \mathrm{pH}: 3+{ }^{18} \mathrm{~F}$ DG (0.08 mM) pH:11 (R2 Reaction) (Figure 2).

The LC/MS analysis has been used to complexation confirmation for R1 and R2 Reactions. Complexation observed with both R1 and R2 (Figure 3A, 4A).

Complexation peak of 10B-18F-DG elevated at 268.8 MW clearly. For confirmation ${ }^{10} \mathrm{~B}-{ }^{18} \mathrm{~F}-\mathrm{DG}$ complex collised with ions in different collision energy $(5,10$, 15) and complex defragmented. Defragmentation and Defragmentation products of complexed ${ }^{10} \mathrm{~B}-{ }^{18} \mathrm{~F}-\mathrm{DG}$ has been observed (Figure 3B, 3C, 3D, 4B, 4C, 4D ).

The peak at $268.8 \mathrm{MW}$ is compatible with our ${ }^{10} \mathrm{~B}-{ }^{18} \mathrm{~F}-$ DG MW calculations. Due to our calculations $2^{10} \mathbf{B}(\mathbf{O H})_{2}-\mathbf{C}_{6} \mathbf{H}_{10}{ }^{18} \mathbf{F O}_{5} \mathrm{MW}$ is about 268 .

According to literature, BoronoPhenylAlanine (BPA) and radioactive tagged ${ }^{18} \mathrm{~F}$-BPA is most usefull Boron carrier for BNCT clinical applications. To compare ${ }^{10} \mathrm{BPA}$ and ${ }^{10} \mathrm{~B}-{ }^{18} \mathrm{~F}-\mathrm{DG}$ uptake yield, invitro comparison analysis was settled.

For ${ }^{10} \mathrm{~B}$ uptake compromise analysis: $0,20,40,80$ $\mu \mathrm{g} / \mathrm{ml} 10 \mathrm{~B}-18 \mathrm{FDG}$ and 10BPA were prepared; Mat LyLu: ATCC JHU-92 cell line $\left(5 \times 10^{6}\right.$ cell) maintained in $\mathrm{CO} 2$ incubator at $370 \mathrm{C}, 0.5 \mathrm{CO}_{2}$, RPMI1640, 10\% FCS, $0.5 \%$ penicillin/streptomycin (Sigma Aldrich).

For ${ }^{10} \mathrm{~B}$ uptake compromise analysis at different concentrations ${ }^{10} \mathrm{~B}-{ }^{18} \mathrm{FDG}(0,20,40,80 \mu \mathrm{g} / \mathrm{ml})$ and ${ }^{10} \mathrm{BPA}$ were add to Mat LyLu cell suspension and incubated for 4 hours. Then cells were washed with phosphate buffer saline (PBS; Sigma-Aldrich, SigmaP4417) solutions for three times and lysed with ultrasonography. Cell debris centrifuged and clean intracellular solution used for ${ }^{10} \mathrm{~B}$ analysis in Agilent 7700 ICP-MS analysis (Figure 4).

Due to statistical analysis, ${ }^{10} \mathrm{~B}-{ }^{18} \mathrm{FDG}$ uptake yield better than ${ }^{10} \mathrm{BPA}(\mathrm{P}<0.001)$ 


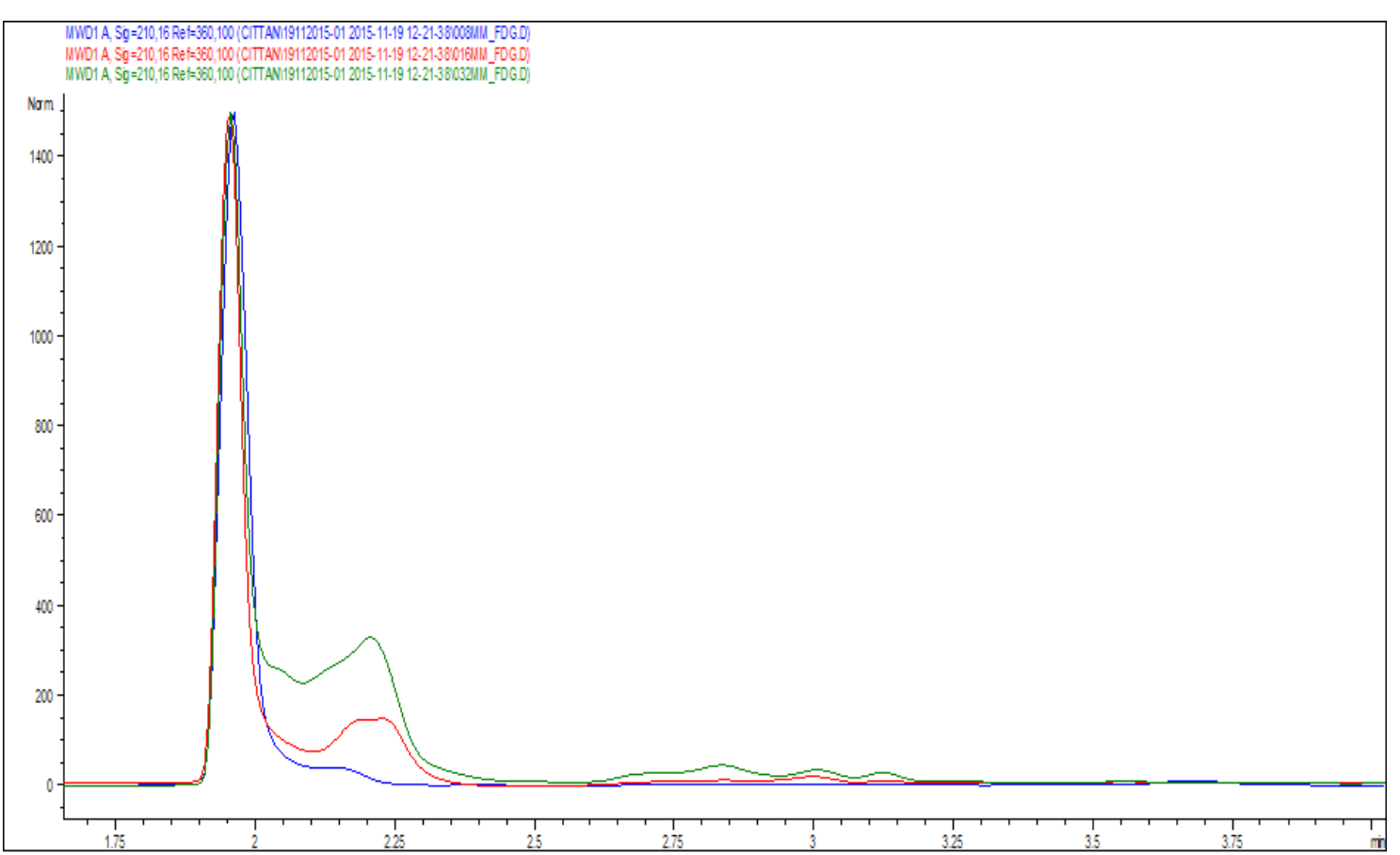

Figure 1: HPLC analysis of different concentration of ${ }^{18} \mathrm{~F}-\mathrm{DG}(0.08,0.16$ ve $0.32 \mathrm{mM})$. (Agilent 1260 Infinity HPLC-DAD)

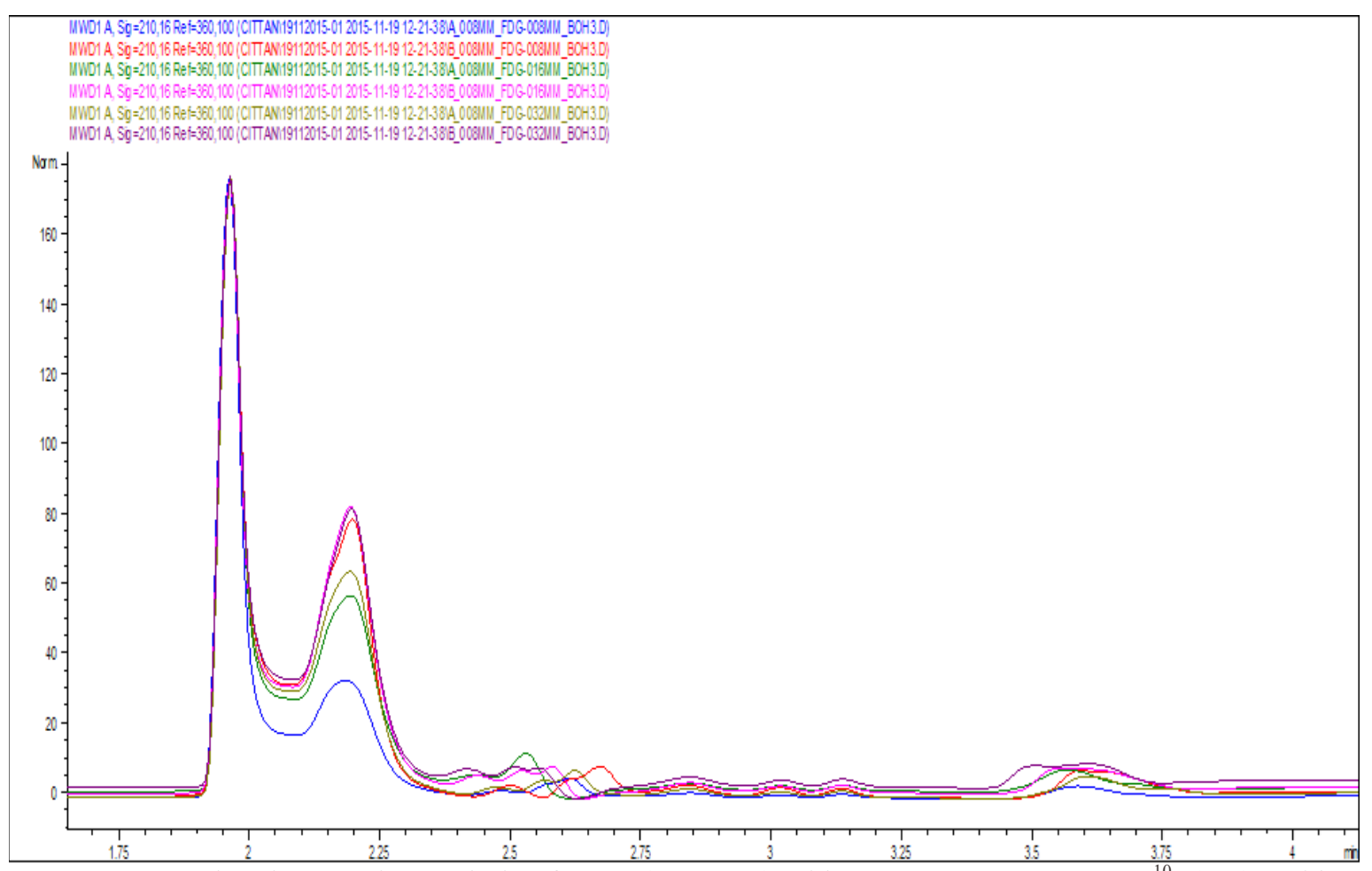

Figure 2: Complexation reaction analysis of FDG $(0.08 \mathrm{mM})$ with $0.08,0.16$ ve $0.32 \mathrm{mM}{ }^{10} \mathrm{~B}(\mathrm{OH}) 3$ with 2 different reaction conditions: FDG pH:3 $+\mathrm{B}(\mathrm{OH}) 3 \mathrm{pH}: 3 \rightarrow \mathrm{pH}: 7$ and ${ }^{18} \mathrm{~F}-\mathrm{DG} \mathrm{pH}: 11+{ }^{10} \mathrm{~B}(\mathrm{OH})_{3} \mathrm{pH}: 3 \rightarrow \mathrm{pH}: 7$. FDG pH:11 $+\mathrm{B}(\mathrm{OH}) 3 \mathrm{pH}: 3 \rightarrow \mathrm{pH}: 7$ reaction yield is more than first reaction (Agilent 1260 Infinity HPLC-DAD) 

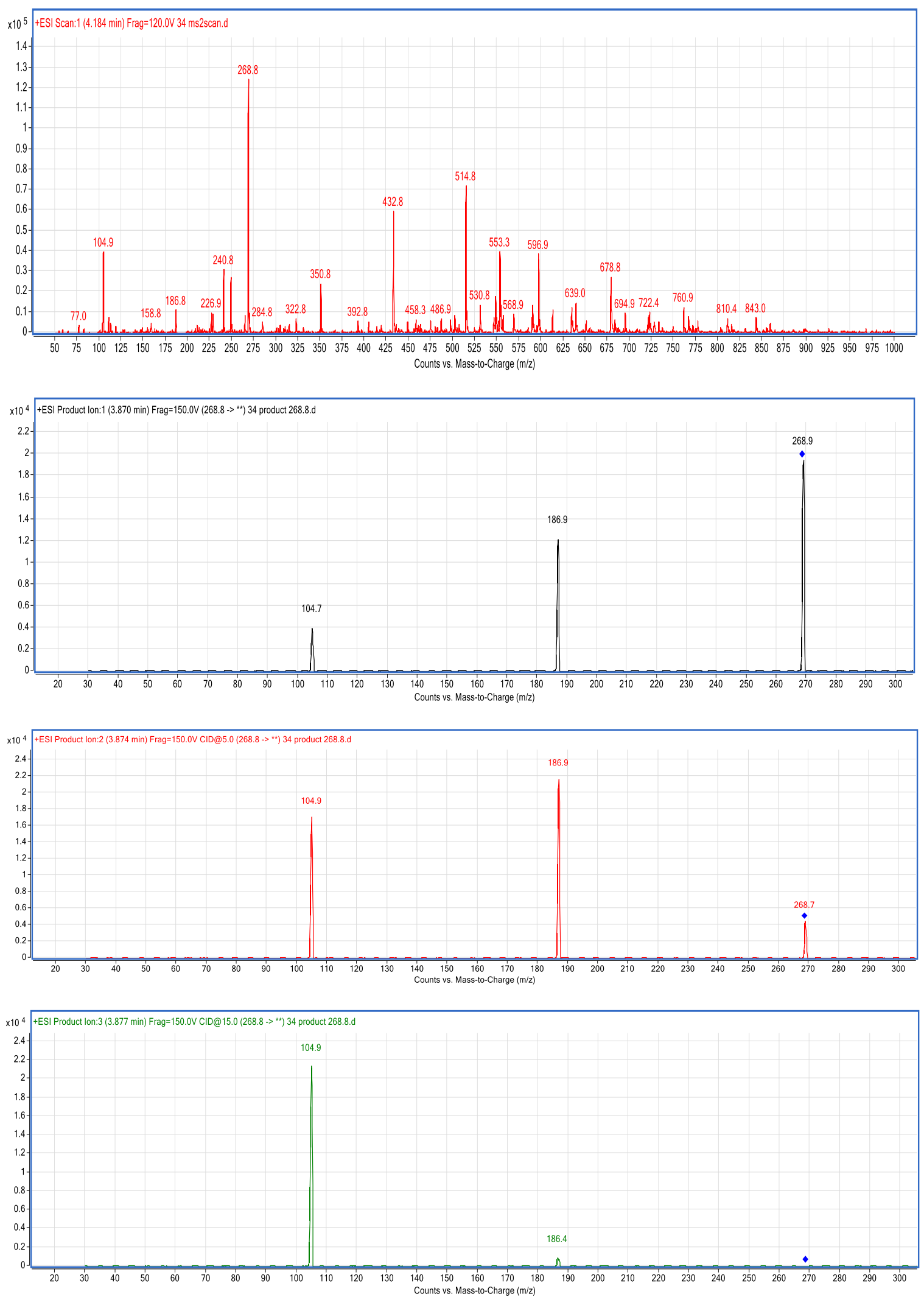

Figure 3: The results of ${ }^{18} \mathrm{~F}-\mathrm{DG} \mathrm{pH}: 3+{ }^{10} \mathrm{~B}(\mathrm{OH})_{3} \mathrm{pH}: 3 \rightarrow \mathrm{pH}: 7$ complexation reaction, Agilent 6420 Triple Quad LC/MS. A) All ${ }^{10} \mathrm{~B}(\mathrm{OH})_{3}-{ }^{18} \mathrm{~F}-\mathrm{DG}$ complexation reaction products B) Complexation product (BFDG) pike at 268.9 MW (Collision Energy =5) C) Degradation product of complex at 268.9 MW (Collision Energy =10). D) Degradation product of complex at 268.9 MW (Collision Energy =15). 

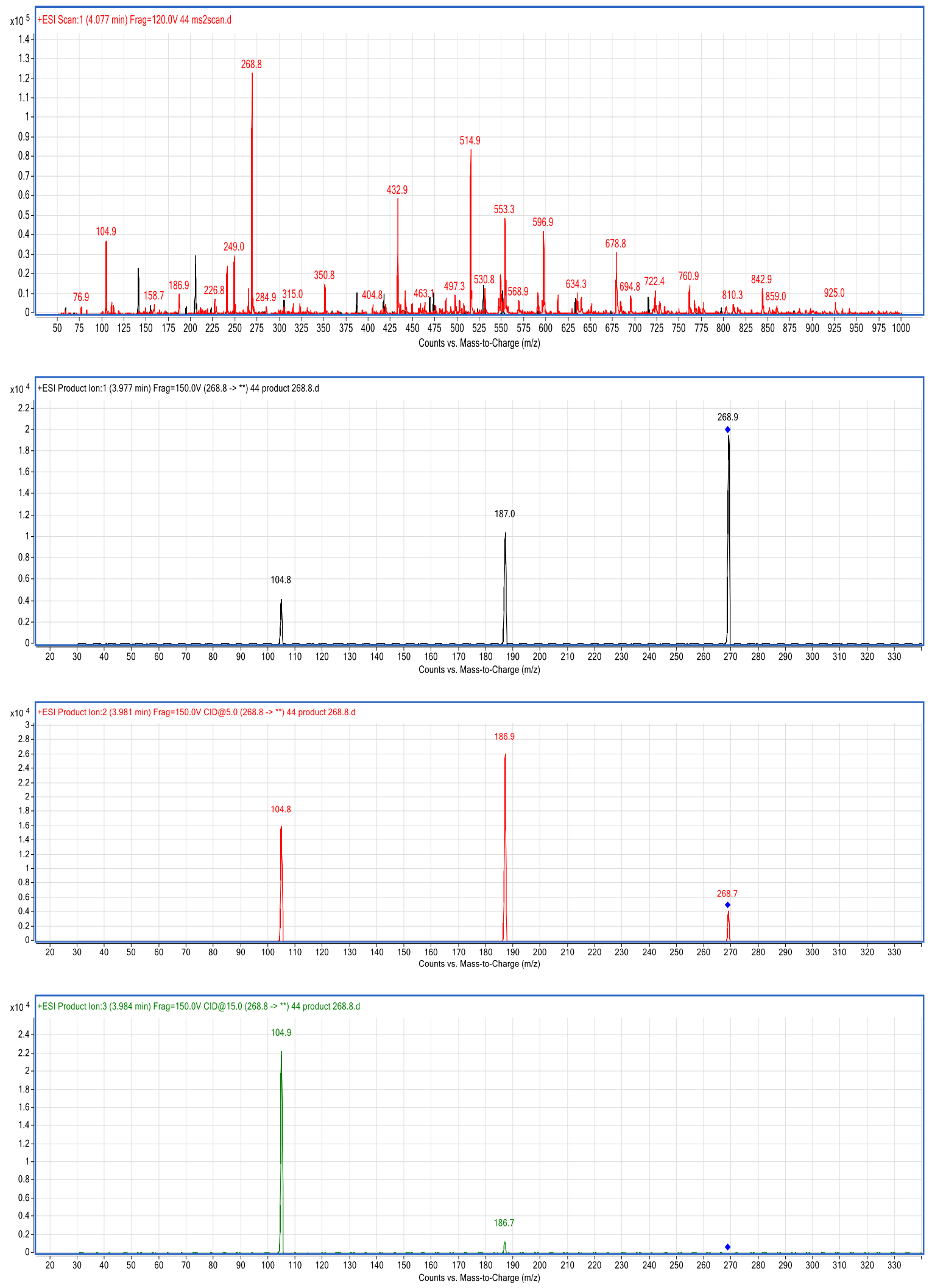

Figure 4: the results of ${ }^{18} \mathrm{~F}-\mathrm{DG} \mathrm{pH}: 11+{ }^{10} \mathrm{~B}(\mathrm{OH})_{3} \mathrm{pH}: 3 \rightarrow \mathrm{pH}: 7$ complexation reaction, Agilent 6420 Triple Quad LC/MS. A) All ${ }^{10} \mathrm{~B}(\mathrm{OH})_{3}-{ }^{18} \mathrm{~F}-\mathrm{DG}$ complexation reaction products B) Complexation product (BFDG) pike at 268.9 MW (Collision Energy =5) C) Degradation product of complex at 268.9 MW (Collision Energy =10). D) Degradation product of complex at 268.9 MW (Collision Energy =15). 


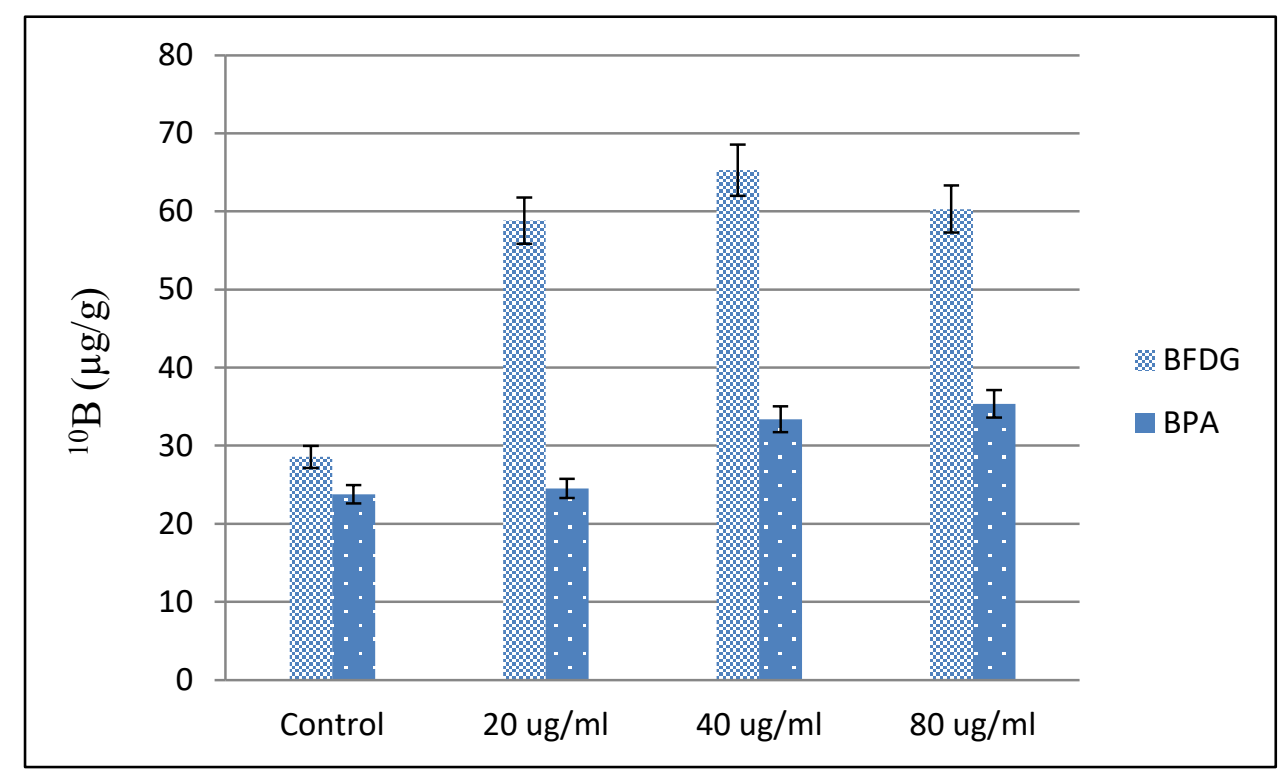

Figure 5: Invitro uptake compromise analysis of ${ }^{10} \mathrm{~B}: 0,20,40,80 \mu \mathrm{g} / \mathrm{ml}{ }^{10} \mathrm{~B}-{ }^{18} \mathrm{FDG}$ and ${ }^{10} \mathrm{BPA}$ were prepared; Mat LyLu: ATCC JHU-92 cell line $\left(5 \times 10^{6}\right.$ cell) maintained in CO2 incubator for 4 hours at $37{ }^{0} \mathrm{C}$, $5 \% \mathrm{CO}_{2}$, RPMI1640, 10\% FCS, 0.5\% penicillin/streptomycin (Sigma Aldrich).

\section{Discussion}

Head and neck cancers such as Glio Blastoma Multiform (GBM), and astrocytomas treatment are among the most difficult type of cancers due to aspects of treatment modality. Chemotherapy and radiotherapy response is inadequite and surgery is quite risky cause of the very low surgical intervention. Due to luck of effective treatment, the life span of patients very low. Due to some survival reports for recurrent cancers the average life time of patient changes between 6-9 months after diagneses of cancer (5).

Because of the success of treatment of head and neck tumors, many groups are working on alternative methods such as Boron Neutron Capture Therapy (BNCT). Private companies such as SUMITOMO carry out clinical trials with their own specific accelerators to prepare this treatment method as a routine treatment protocol $(1,2,3,4,5,6)$.

To date, approximately 200 BNCT clinical trials have completed and some of them reported worldwide. Beside complete recovery of some patients, average patient survival reported more than 24 months (9).

The biggest problem of BNCT as a routine treatment is the cost problem. Beside, thermal, epithermal neutron source, the boron carrier agent cost is the biggest obstacle to the routine implementation of BNCT.

As indicated in literature complexation of boron with sugar compounds based on $\mathrm{pH}$ reaction.
Lorand and Edwards published work quantifying the affinity of boric and phenylboronic acids for simple diols (e.g.-ethylene glycol, catechol) and common monosaccharides (i.e.-glucose, fructose, mannose, galactose) $(10,11)$.

The covalent product between a boronic acid and a diol is termed a boronate ester, analogous to a carboxylate ester. These interactions are favoured at basic $\mathrm{pH}$ ranges where the tetrahedral boronate ester is formed (Figure 6). The interchange between boron acids and divalent ligands in aqueous solution can be complex and varied depending on $\mathrm{pH}$.<smiles>[R]C(O)C([R])C(O)O</smiles>

Figure 6: Boric Acid interactions with sugar (10)

In our previous studies, success of boron targeting of deoxy-d-glucose to tumor tissues (borono deoxy-dglucose, BDG) has been shown which deoxy-dglucose routinely used for $18 \mathrm{~F}$ targeting to tumour tissue in positron emition tomography (PET) for tumor detection and staging.

In this study, we proposed a simple $\mathrm{pH}$ reaction method for the synthesis of ${ }^{18} \mathrm{~F}-{ }^{10} \mathrm{~B}-\mathrm{DG},\left({ }^{18} \mathrm{~F}-\mathrm{BDG}\right)$ which could be used beside to ${ }^{18} \mathrm{~F}-{ }^{10} \mathrm{~B}-\mathrm{PA},\left({ }^{18} \mathrm{~F}-\mathrm{BPA}\right)$ 
Due to invitro uptake analysis, synthesized ${ }^{18} \mathrm{~F}-\mathrm{BDG}$ has shown more efficient carrier properties than BPA to the respect of boron accumulation test on cancer cells.

Acknowledgement: Synthesis of Borono Fluoro Deoxy D glucose as Boron carrier for Boron neutron capture therapy (BNCT) entitled project was supported by Celal Bayar University Scientific Research Department (CBU BAP 2014-115).

Conflict of Interest: The authors declare no potential conflicts of interest with respect to the research, authorship, and/or publication of this article.

Author's Contributions: ZA, GO, HO: Design of study, ZA, TO: Complexation studies, Invitro analysis Collecting of patients data, Patient examination and operation, writing and revision of article, $\mathrm{HC}$ : Statistical analysis of findings.

Ethical issues: All Authors declare that Originality of research/article etc... and ethical approval of research, and responsibilities of research against local ethics commission are under the Authors responsibilities. The study was conducted due to defined rules by the Local Ethics Commission guidelines and audits.

\section{References}

1. Barth, R. F., Yang, W., Rotaru, J. H., Moeschberger, M. L., Boesel, C. P., Soloway, A. H., ... \& Goodman, J. H. (2000). Boron neutron capture therapy of brain tumors: enhanced survival and cure following blood-brain barrier disruption and intracarotid injection of sodium borocaptate and boronophenylalanine. International Journal of Radiation Oncology* Biology* Physics, 47(1), 209-218.

2. Barth, R. F., Vicente, M. H., Harling, O. K., Kiger, W. S., Riley, K. J., Binns, P. J., ... \& Kawabata, S. (2012). Current status of boron neutron capture therapy of high grade gliomas and recurrent head and neck cancer. Radiation Oncology, 7(1), 146.
3. Moss, R. L. (2014). Critical review, with an optimistic outlook, on Boron Neutron Capture Therapy (BNCT). Applied Radiation and Isotopes, 88, 2-11.

4. Coderre, J. A., Elowitz, E. H., Chadha, M., Bergland, R., Capala, J., Joel, D. D., ... \& Chanana, A. D. (1997). Boron neutron capture therapy for glioblastoma multiforme using p-boronophenylalanine and epithermal neutrons: Trial design and early clinical results. Journal of neurooncology, 33(1), 141-152.

5. Aihara, T., Hiratsuka, J., Morita, N., Uno, M., Sakurai, Y., Maruhashi, A., ... \& Harada, T. (2006). First clinical case of boron neutron capture therapy for head and neck malignancies using 18F-BPA PET. Head \& neck, 28(9), 850-855.

6. Akan, Z., Demiroglu, H., Avcibasi, U., Oto, G., Ozdemir, H., Deniz, S., \& Basak, A. S. (2014). Complexion of Boric Acid with 2-Deoxy-D-glucose (DG) as a novel boron carrier for BNCT. Medical Science and Discovery, 1(3), 65-71.

7. Akan, Z., Ozdemir, H., Oto, G., Deniz, S., Kacar, O., Basak, A. S., ... \& Demir, G. (2014). Genotoxicity and Cytotoxicity of novel 10B carrier ((2R)-4, 5, 6-trihydroxy2-(hydroxymethyl) tetrahydro-2H-pyran-3-yl) boronic acid. Medical Science and Discovery, 1(4), 96-108.

8. Akan, Z., Ozdemir, H., Oto, G., Uslu, H., Turkmen, M., \& Yuksel, M. B. (2016). The treatment of metastatic prostate carcinoma with BNCT in the ITU TRIGA MARKII reactor on rat model.

9. Miyatake, S. I., Kawabata, S., Yokoyama, K., Kuroiwa, T., Michiue, H., Sakurai, Y., ... \& Ono, K. (2009). Survival benefit of boron neutron capture therapy for recurrent malignant gliomas. Journal of neuro-oncology, 91(2), 199.

10. Pappin B, Kiefel MJ, Houston TA (2012). Boroncarbohydrate interactions. InCarbohydratesComprehensive Studies on Glycobiology and Glycotechnology. InTech.

11. Böeseken J. (1913) On the storage of hydroxyl groups of polyoxide compounds in space. The configuration of saturated glycols and of alpha- and beta-glycose. Ber. Dtsch. Chem. Ges., 46: 2612-2628.

Copyright (C) 2016 The Author(s); This is an open-access article distributed under the terms of the Creative Commons Attribution License (http://creativecommons.org/licenses/by/4.0), which permits unrestricted use, distribution, and reproduction in any medium, provided the original work is properly cited. All Rights reserved by international journal of Medical Science and Discovery. 